\title{
Criminal evidence in modern scientific methodsIn Iraqi law
}

\author{
Dr. Khalied Mohammad Ajaj \\ Department of Law/ College of Law/ Cihan University/ Sulaimanya
}

\begin{abstract}
Criminals often try to conceal the evidence of the commission of the crime. The use of certain means to detect the crime must have been used. The newly discovered scientific means have contributed to the identification of the evidence of crimes by collecting, examining and analyzing them. The field of modern technology and the medical and psychological field has a great impact on the detection of criminals and their motives. That the development in the field of organized crime by criminal gangs of scientific and technical methods in the commission of crimes prompted States to encourage scientific research and the invention of modern scientific means to help in the detection of crimes and the removal of ambiguity, and the criminal investigation devices to identify the reality of criminal facts and the personality of the perpetrators, The use of the scientific means produced by rapid scientific development is vital to the success of criminal investigation in the detection of crimes.In this research, there will be some scientific means, and then we will explain the position of the Iraqi legislator on its use in criminal evidence
\end{abstract}

\section{Hypnosis}

In fact, this label is known as the original and the original is hypothetical hypnosis because it is done by inspiration and concentration of attention .Fathy, 1969 ).It is known as the hypothetical sleep of some of the apparent queens of the mind, which can be induced by the idea of sleeping. Awad, 2010). As the sensory selfblockage of the sleeper and remain a strange self and the same hypnotist. (Al-Nabarawi, 1969) Thus paralyzing the basic function of the human mind d. ( Al-Mulla, 1975) .It is also known as a state of mental concentration characterized by a complete or partial disappearance of consciousness around the periphery while maintaining a kind of awareness centered around a specific point. (Nabih, , 2010).Hypnosis is at three degrees according to its depth and strength. Some people can be hypnotized to a small degree, others can be easily hypnotized and others can deepen their sleep. People with weak will are more susceptible to hypnosis than ordinary people or strong will. As for the legitimacy of the use of hypnosis as a means of criminal proof In Iraqi law we see that the use of such means has been prohibited. This is evident in the text of Article 22 (a) of the Constitution of the Executive of 2005, which stipulates that "human dignity is protected and prohibits the exercise of any kind of physical and psychological torture. ) Of the Code of Criminal Procedure of Iraq, which prohibited the use of means of pressure on the accused, including psychological means as a picture of the (psychological impact) and therefore the use of hypnosis is not permissible at all stages of the investigation because it represents an attack on self-confidence and its secrets, Represents a constitutional and legal violation.

\section{NARCOTIC DRUGS}

It is also called the Truth Serum, which means injecting the accused with narcotic drugs, which causes him to sleep a deep sleep for between 5-20 minutes, and then wakes up. He is a classmate of memory and speaks automatically or answers certain questions. The incident shows its reasons, motivations and circumstances. It is worth mentioning that these substances do not make a person lose consciousness, but make him at the same time cannot control his will, resulting in a desire to express and express internal feelings as a result of inspiration, and then can detect the motives and pent-up desires, allowing the investigator access To new evidence or to strengthen the existing evidence to ask the person to ask him and answer them (Al-Jawad, 2008).Legitimacy of the use of drugs in Iraqi law:Article 37 (I / C) stipulates that "all forms of psychological and physical torture, inhuman treatment and no evidence of any confession shall be taken away." The Iraqi constitution explicitly prohibits the use of all forms of psychological and physical torture. Coercion, threat or torture, and the injured person seeking compensation for material and moral damage caused by the law (article 127 of the Code of Criminal Procedure states that this is not permissible under the name of "... the use of drugs ... and drugs").

\section{Lie Detector}

It is the device that records some physiological changes (blood pressure, breathing, degree of resistance to the skin of the electrical current) that appear on the individual during the investigation, and study these changes through the analysis of the graphs recorded by the device and by evaluating all the evidence available in the investigation can then Verifying the truthfulness or falsehood of the person in the subject of the test in his

\begin{tabular}{llr}
\hline DOI: $10.9790 / 0837-2204082224$ & www.iosrjournals.org & $22 \mid$ Page
\end{tabular}


answer to the questions addressed to him.( Al-Abadi, 2008). This device works on the basis that the person who lies is growing anxious and show him other emotional variables make him troubled. The lie detector consists of three sections, each of which performs a specific function. These sections are the blood pressure department, the respiratory section and the skin resistance section, and we will explain it as follows:

Section I: Department of Blood Pressure: This section is to know the changes in blood pressure, heart rate and the result of emotions, which appear on the person who is subjected to the experience when lying, as these involuntary recordings by a special index in the form of graphic lines. Al. Taya, 2011).

Section II: Respiratory section: It is concerned with measuring the movement of the breath and the accompanying change because of psychological emotions, as recording cases of inhalation and exhalation and changes that occur from this movement because of the emotions that occur during the investigation during the investigation. (Al-Anbuge, 2012).

Section III: Department of skin resistance: This section is to monitor the minor changes that occur on the skin during the passage of a light electric current, which occur as a result of the emotions usually associated with the saying of lying. Each of these sections has a feather that draws graphs on a moving paper. As the paint of the respiratory section of the charts at the top of the paper and the blood pressure at the bottom of the paper, while the feather for the resistance to the electrical current lines in the middle of the paper Al-Shawi, , 2009).

As for the position of the Iraqi legislator on the use of this device, we see that there is nothing to permit or prohibit the use of a lie detector or other means of modern criminal evidence during the investigation, but it is understood from the existing texts that such devices are not allowed. Article 22 ) Of the Constitution (2005), which prohibits the exercise of any kind of physical and psychological torture, as it is incompatible with the constitutional rights and guarantees guaranteed to the accused, so it is not permissible for the accused to waive him. The Criminal Procedure Law, although not expressly prohibiting the use of this method to extract the statement of the accused, but it was implicitly stated through the text of Article (127) of the Code of Criminal Procedure through the term ((psychological impact)), which include All factors affecting the psyche of the accused, including a lie detector.

\section{MONITORING TELEPHONE AND ELECTRONIC COMMUNICATIONS}

It is intended to deliberately listen and record private conversations, whether direct or indirect, whether it is exchanged by people in front of each other or by means of telecommunications and telecommunications (Awad, 1977). The tremendous scientific development in all fields, including the electronic field, has seen the emergence of sophisticated devices that can monitor and record telephone calls which may in turn be used as proof of proof or disclosure of a secret to a particular person. This development in the means of communication has contributed to the adoption of the whole world by a remarkable way in which no one can abandon it in all areas, including crime. As a group of criminals carry out their crime, they must communicate with each other to agree on the steps and coordination of the lawyer ( Al-Shoman, 2011).

The use of means of communication in the field of crime cannot be without legislation can also take the role of the assistance of the security and investigative authorities in order to detect the crime by allowing eavesdropping and recording of telephone calls, which allows to contribute to the arrest of criminals and the dismantling of cells. At the same time, the use of modern means of communication in criminal evidence may cause many problems and legal obstacles, such as violation of the right to privacy and disclosure of the secrets of individuals. This has caused embarrassment in many legislations that went between supporters and opponents of the use of such methods. Husseini, 1972).

In general, because of its attachment to the human right to personal privacy, which it stressed and the need to protect many international and regional conventions and conventions, most modern constitutions stipulated that they cannot be observed except in exceptional circumstances. The telephone calls are part of the private life of individuals as they may not be infringed except in a very narrow range, and on the basis of this, it is not valid to monitor them and harm their confidentiality. If that leads to revealing the truth. (Saleh, 1997).

As far as theposition of the Iraqi legislator of monitoring communications, there is no legislative provision in the Code of Criminal Procedure of Iraq nor any special law regulating the issue of monitoring eavesdropping and monitoring communications, but some jurisprudence believes that the acceptance of registration and eavesdropping was implicitly .( Al-Husseini, 2015).

In accordance with the principle of not limiting the criminal evidence provided for in Article 213 (a) of the Code of Criminal Procedure (which stipulates that a) The court shall judge the case based on its conviction that it has evidence provided in any of the investigation or trial roles. Testimony, witnesses, minutes of investigation, records, other official reports, expert reports, technicians, evidence and other evidence prescribed by law).Was among the Iraqi constitution in 2005 on the inadmissibility of communications and correspondence control only in exceptional cases as provided for Article 40 thereof that ((freedom of communication and correspondence, postal, telegraph and telephone, electronic and other guaranteed and may not be monitored, wiretapped or disclosed except for legal and security necessity and the decision judicial)) In all cases, even 
though it might be a constitution and a law to resort to this measure in order to obtain testimony and approval of the accused, it has to be the availability of several necessary guarantees, including the necessity of security and the approval of the judicial authorities, and noted that the Iraqi constitution, leaving it to Ajtha Judicial authorities, which is not consistent with the risks arising from resorting to this measure in the absence of a legal organization. Therefore, we believe that the Code of Criminal Procedure should include a provision regulating the conditions under which wiretapping, communications monitoring, or the enactment of a special law may be resorted to in order to prevent violation of the right of privacy of individuals and restriction of their freedoms.It should be noted that the Iraqi National Safety Law No. 4 of 1965 has authorized recourse to telecommunications control in Article IV (12). But in a very narrow way to obtain the statements of the accused in exceptional circumstances, specifically in the case of the declaration of emergency in the country. It is worth mentioning that judicial monitoring must be obtained before the start of eavesdropping and surveillance. In other cases, telecommunications companies are approached to obtain information regarding the telephone number of a telephone subscriber, as well as to know incoming and outgoing calls such as telephone use in the crime of threat, defamation and terrorism.

\section{CONCLUSION}

As for the position of the Iraqi legislator, we see that the use of such means has been prohibited. This is evident through the provisions of Article 22 (a) and Article 37 (I / C) of the Iraqi Constitution of 2005 which stipulates that "Human dignity is inviolable and prohibits the exercise of any kind of Physical and psychological torture), as well as the text of Article (127) of the Code of Criminal Procedure of Iraq, which prohibited the use of means of pressure on the accused, including psychological means as a picture of the (psychological impact) and therefore the use of modern scientific methods can be used in very narrow limits. Therefore, we call on the Iraqi legislator to enact laws that allow the use of such means without violating the right of individuals as they contribute to the detection of crime.

\section{BIBLIOGRAPHY}

[1] Dr.. Mohamed Fathy, Criminal Psychology note and action, c 1, i 4, Press Happiness, Cairo, 1969, p. 285.

[2] RamziRiadAwad, The Criminal Judge's Power in Estimating Evidence, Comparative Study, Dar AlNahda Al-Arabiya, Cairo, 2010, p. 153.

[3] Muhammad Sami al-Nabarawi, interrogation of the accused, Dar al-Nahda al-Arabiya, Cairo, 1968, 1969, p.115

[4] Dr. Sami Sadeq Al-Mulla, Confession of the Accused I 2, International Press, Cairo, 1975, p. 180.

[5] Dr.NisreenAbdelhamidNabih, Is it permissible to resort to hypnosis and narcotic drugs as a means to lure the accused to find out the truth during investigations, i., Al-Wafa Legal Library, Alexandria, 2010, p. 7.

[6] (Murad Ahmad al-Abadi, the confession of the accused and its impact on proof, comparative study, Dar Al-Thaqafa for publication and distribution, Amman, Jordan, 2008, p.77.

[7] Hani Mohamed Taya, Modern Methods in Criminal Evidence, PhD thesis submitted to the Faculty of Law, Cairo University, 2011, p. 65.

[8] (Adnan Zidan Hassoun Al-Anbuge, recognition and importance in the criminal evidence, Sabah Library, Baghdad, 2012, p. 37.

[9] .( Dr. Sultan Al-Shawi, Principles of Criminal Investigation, Legal Library, Baghdad, 2009, p. 222.

[10] Dr. Awad Mohamed Awad, General Principles in the Code of Criminal Procedure, Knowledge Establishment, Alexandria, 1977, p. 404.

[11] Nasr Al-Shoman, Modern Criminal Technology and its Importance in Criminal Evidence, I, No Publication and Place of Publication, 2011, p.87.

[12] Sami Husseini, general theory of inspection in law Egyptian and Comparative, Ph.D., University, Ain Shams University, Dar al-Nahda al-Arabiya, Cairo, 1972, p. 344.

[13] Dr. Nael Abdul Rahman Saleh, Lectures in the Foundations of Criminal Trials, 1, Dar Al Fikr for Printing and Publishing, Amman, Jordan, 1997, p.67.

[14] . Ammar Abbas Al-Husseini, Criminal Investigation, I 1, Halabi Publications, Beirut, Lebanon, 2015, p.67. 